\title{
Character Association and Path Analysis in Coloured Potato (Solanum tuberosum L.)
}

\author{
S. Nayak $^{1^{*}}$, A. Mishra ${ }^{1}$, D. Ghosal ${ }^{1}$ and G. S. Sahu ${ }^{2}$ \\ ${ }^{1}$ All India Coordinated Research Project on Potato, OUAT, Bhubaneswar, India \\ ${ }^{2}$ Department of Vegetable Science, College of Agriculture, OUAT, Bhubaneswar, India \\ *Corresponding author
}

\section{Keywords}

Coloured potato genotypes,

Association among

morphological

characters, Path

analysis

Article Info

Accepted:

22 March 2020

Available Online:

10 April 2020

\section{A B S T R A C T}

A field experiment was conducted in the Research Farm of All India Coordinated Research Project on Potato, OUAT, Bhubaneswar, Odisha, India to study the association among morphological traits in twenty one potato genotypes including coloured ones. The experiment was laid out in Randomized block design with four replications. It was observed that tuber yield plant $^{-1}$ had significantly positive correlation with plant height, shoots plant $^{-1}$, compound leaf length, leaf breadth, Compound leaf area, compound leaves plant ${ }^{-1}$, average tuber weight and tubers plant ${ }^{-1}$ at both phenotypic and genotypic level. Similarly, shoots per plant at 45 days exhibited maximum direct positive effect on tuber yield followed by average single tuber weight, plant height at 60 days, compound leaf breadth and number of tubers per plant. This indicates that selection for these traits will be rewarding because they have more direct contribution towards tuber yield.

\section{Introduction}

Potato (Solanum tuberosum L.), a member of the family Solanaceae, is one of the major cultivated food crops in the world. It ranks fourth after rice, wheat and corn (FAO STAT, 2017). In the east Indian state of Odisha, potato is cultivated over an area of 25.03 thousand hectares with production of 2.94 lakh tonnes and productivity of 12.04 metric tonnes per hectare (HAPIS, Odisha. 2017).
Potato production in Odisha accounts $3.3 \%$ of the total vegetable production and $3.78 \%$ of the total area under vegetable production of Odisha.

One of the most important phenotypic traits of potato is the skin colour. Most of the commercial potatoes bred till today are of white or yellow colour. Few varieties have different colours due to anthocyanin pigmentation. Lot of variability is seen 
among the coloured potato genotypes. Coloured potatoes may have purple, red, pink, yellow or blue coloured skin. The skin colour of potato tuber results from differences in accumulation of anthocyanin pigments (Jong et al., 2003). Colorations originate from the accumulation of different classes of pigments, that is, carotenoids and anthocyanins (Brown, 2006; Brown et al., 2007).

Carotenoids impart white, yellow or saffron yellow colour to the skin and flesh (Brown, 2006; Brown, 2008). Colour of the skin and flesh has considerable effect on consumer acceptance (Crisosto et al., 2003). Coloured potatoes have better taste, appearance, protein content (Kita et al., 2015) and are rich source of antioxidants (Brown et al., 2003 ; Brown, 2008; Jansen and Flamme, 2006) for which they draw the attention of researchers as well as consumers.

Traditionally red skinned potatoes have gained popularity in eastern India but now it is gaining momentum towards preference in north western and west central plains too which account for nearly $75 \%$ of potato production in India (Luthra et al., 2003).

Keeping in view the health benefit and marketability in India, some coloured varieties have been released by ICAR-CPRI, Shimla such as, Kufri Arun (Red), Kufri Lalima (Pink), Kufri Lalit (Light red), Kufri Kanchan (Pink), Kufri Neelakanth (Dark Purple), etc. The market price of coloured potatoes is often higher than normal varieties. Considering the potential of coloured skin potato, there is a need to evaluate varieties suitable for cultivation under different agroecological conditions.

However, limited studies have been conducted to correlate the contribution of easily marked morphological characters towards final tuber yield, particularly in coloured potato. Thus the present investigation was carried out to study the association of different morphological characters with tuber productivity.

\section{Materials and Methods}

The experiment was carried out at All India Co-ordinated Research Project on Potato, OUAT, Bhubaneswar, during rabi, 2018-19 with 21 potato genotypes including 15 coloured potato genotypes. The experiment was laid out in Randomized Block Design (RBD) with four replications. In each plot, a genotype was grown in five rows having twelve plants per row, spaced $60 \mathrm{~cm}$ between rows and $20 \mathrm{~cm}$ between plants. From randomly selected 5 plants per plot, observations were recorded for thirteen characters viz., plant height $(\mathrm{cm})$ at 30days, 45 days and 60 days; shoots plant ${ }^{-1}$ at 30 days, 45 days and 60 days; leaf length $(\mathrm{cm})$, leaf breadth $(\mathrm{cm})$, number of compound leaves plant ${ }^{-1}$, compound leaf area $\left(\mathrm{cm}^{2}\right)$, tubers plant $^{-1}$, average tuber weight $(\mathrm{g})$ and tuber yield plant $^{-1}(\mathrm{~g})$ at 75 days. Genotypic and phenotypic correlation coefficients and path coefficient values were worked out following Singh and Chaudhary (1979).

\section{Results and Discussion}

In general, correlation studies are highly beneficial in selecting superior genotypes for any population improvement programme (Robinson, 1966). Interrelationship amongst quantitative characters both at genotypic and phenotypic levels helps in effective selection of a new genotype. The genotypic and phenotypic correlation coefficient values of component characters show their extent of positive or negative association with tuber yield (Table 1). The path matrix using genotypic correlation coefficient values exhibit the direct contribution of a component trait towards tuber yield (Table 2). 
Plant height at 30 days showed significant positive correlation with shoots plant ${ }^{-1}$ and compound leaf length at both phenotypic and genotypic levels. Plant height at 30 days exhibited positive correlation with yield which corroborates the findings of Sattar et al., (2007), Panigrahi et al., (2017) and Khayatnezhad et al., (2011).

Plant height at 30 days exhibited significant positive correlation with the same character at 45 and 60 days as well as shoots per plant which highlights the importance of early vigour on crop growth and productivity. Significant correlation of plant height only at 30 days with tuber yield might be due to proper partitioning of photosynthates after vigorous growth at early stage. Channelization of photosynthates towards tuber development might be responsible for slow shoot growth at later stages.

Shoots plant ${ }^{-1}$ was found to be significantly and positively associated with the tuber yield plant $^{-1}$. This result is in agreement with the findings of Panigrahi et al., (2017). This character has also significant positive association with height of the plant at 30 and 45 days, compound leaf length, leaf breadth, number of compound leaves per plant and tubers per plant.

Compound leaf length had positive correlation with plant height at 30 days, shoots per plant, compound leaf area, leaf number, tubers per plant and average single tuber weight but negatively correlated with compound leaf breadth. This character exhibited significant and positive correlation with yield per plant both at phenotypic and genotypic levels.

Compound leaf breadth had positive correlation with plant height at 30 days, shoots per plant but negatively correlated with compound leaf length, compound leaf area, leaf number, tubers per plant and average single tuber weight. This character exhibited significant and positive correlation with yield per plant both at phenotypic and genotypic levels.

Compound leaf area had positive correlation with plant height at 30 days, compound leaf length but negative correlation with shoots per plant, leaf breadth and tubers per plant. This character exhibited significant positive correlation with yield per plant both at phenotypic and genotypic levels.

Number of tubers plant ${ }^{-1}$ was found to be positively associated with tuber yield plant ${ }^{-1}$. This result is in agreement with the findings of Sattar et al., (2007), Luthra et al., (2018) and Khayatnezhad et al., (2011). Further, the number of tubers per plant had significant positive correlation with plant height, shoots per plant, compound leaf length, leaf breadth and tubers per plant but negative correlation with compound leaf area and average single tuber weight.

Number of leaves per plant was found to be significantly and positively associated with tuber yield plant ${ }^{-1}$. This result is in agreement with the findings of sattar et al., (2007). Further the number of compound leaves per plant had significant positive correlation with plant height, shoots per plant, compound leaf length, leaf breadth and tubers per plant but negative correlation with compound leaf area.

Average weight of single tuber had positive correlation with plant height at 30 days, shoots per plant, compound leaf length and leaf breadth but negative correlation with tubers per plant. This character exhibited highest significant positive correlation with yield per plant both at phenotypic and genotypic levels. This result was in agreement with the findings of Khayatnezhad et al., (2011). 
Table.1 Correlation coefficient among yield attributing morphological characters of 21 genotypes

\begin{tabular}{|c|c|c|c|c|c|c|c|c|c|c|c|c|c|}
\hline & & PH 30d & PH 45d & PH 60d & SP 30d & SP 45d & SP & CLL & CLB & CLA & NCL & TPP & ASTW \\
\hline \multirow{2}{*}{$\begin{array}{l}\text { PH } \\
\text { IEd }\end{array}$} & $r_{g}$ & $0.580^{* *}$ & & & & & & & & & & & \\
\hline & $r_{P}$ & $0.607^{* *}$ & & & & & & & & & & & \\
\hline \multirow{2}{*}{ PH } & $r_{g}$ & $0.495^{* *}$ & $0.845^{* *}$ & & & & & & & & & & \\
\hline & $\mathrm{r}_{\mathrm{P}}$ & $0.519^{* *}$ & $0.904^{* *}$ & & & & & & & & & & \\
\hline \multirow{2}{*}{ SP } & $r_{g}$ & $0.344^{* *}$ & $0.036^{\mathrm{NS}}$ & $-0.081^{\mathrm{NS}}$ & & & & & & & & & \\
\hline & $\mathrm{r}_{\mathrm{P}}$ & $0.370^{* *}$ & $0.039^{\mathrm{NS}}$ & $-0.091^{\mathrm{NS}}$ & & & & & & & & & \\
\hline \multirow{2}{*}{ SP } & $r_{g}$ & $0.438^{* *}$ & $0.026^{\mathrm{NS}}$ & $-0.082^{\mathrm{NS}}$ & $0.954^{* *}$ & & & & & & & & \\
\hline & $\mathrm{r}_{\mathrm{P}}$ & $0.456^{* *}$ & $0.036^{\mathrm{NS}}$ & $-0.077^{\mathrm{NS}}$ & $0.968^{* *}$ & & & & & & & & \\
\hline \multirow{2}{*}{ SP } & $r_{g}$ & $0.454^{* *}$ & $0.065^{\mathrm{NS}}$ & $-0.047^{\mathrm{NS}}$ & $0.921^{* *}$ & $0.958^{* *}$ & & & & & & & \\
\hline & $r_{P}$ & $0.483^{* *}$ & $0.078^{\mathrm{NS}}$ & $-0.035^{\mathrm{NS}}$ & $0.948^{* *}$ & $0.982^{* *}$ & & & & & & & \\
\hline \multirow[t]{2}{*}{ CLL } & $r_{g}$ & $0.259^{*}$ & $0.134^{\mathrm{NS}}$ & $0.169^{\mathrm{NS}}$ & $0.337^{* *}$ & $0.384^{* *}$ & $0.357^{*}$ & & & & & & \\
\hline & $\mathrm{r}_{\mathrm{P}}$ & $0.307^{* *}$ & $0.189^{\mathrm{NS}}$ & $0.199^{\mathrm{NS}}$ & $0.400^{* *}$ & $0.449^{* * *}$ & $0.416^{*}$ & & & & & & \\
\hline \multirow[t]{2}{*}{ CLB } & $r_{g}$ & $0.104^{\mathrm{NS}}$ & $0.083^{\mathrm{NS}}$ & $-0.003^{\mathrm{NS}}$ & $0.209^{\mathrm{NS}}$ & $0.189^{N}$ & 0.169 & - & & & & & \\
\hline & $r_{P}$ & $0.190^{\mathrm{NS}}$ & $0.152^{\mathrm{NS}}$ & $-0.035^{\mathrm{NS}}$ & $0.268^{*}$ & $0.245^{*}$ & $0.236^{*}$ & - & & & & & \\
\hline \multirow[t]{2}{*}{ CLA } & $r_{g}$ & $0.188^{\mathrm{NS}}$ & $0.011^{\mathrm{NS}}$ & $0.283^{* *}$ & $-0.117^{\mathrm{NS}}$ & - & - & 0.153 & - & & & & \\
\hline & $r_{P}$ & $0.209^{\mathrm{NS}}$ & $0.016^{\mathrm{NS}}$ & $0.303^{* *}$ & $-0.127^{\mathrm{NS}}$ & - & - & 0.174 & - & & & & \\
\hline \multirow[t]{2}{*}{ NCL } & $r_{g}$ & $0.131^{\mathrm{NS}}$ & $0.225^{*}$ & $0.173^{\mathrm{NS}}$ & $0.424^{* *}$ & $0.408^{* *}$ & $0.448^{*}$ & $0.323^{*}$ & 0.31 & - & & & \\
\hline & $r_{P}$ & $0.165^{\mathrm{NS}}$ & $0.277^{*}$ & $0.218^{*}$ & $0.471^{* *}$ & $0.453^{* *}$ & $0.493^{*}$ & $0.387^{*}$ & 0.43 & $-0.230^{*}$ & & & \\
\hline \multirow[t]{2}{*}{ TPP } & $r_{g}$ & $0.165^{\mathrm{NS}}$ & $0.318^{* *}$ & $0.195^{\mathrm{NS}}$ & $0.296^{* *}$ & $0.255^{*}$ & $0.217^{*}$ & 0.155 & 0.22 & - & $0.477^{* *}$ & & \\
\hline & $r_{P}$ & $0.178^{\mathrm{NS}}$ & $0.404^{* *}$ & $0.251^{*}$ & $0.404^{* *}$ & $0.324^{* *}$ & $0.287^{*}$ & $0.230^{*}$ & 0.38 & - & $0.633^{* *}$ & & \\
\hline \multirow{2}{*}{$\begin{array}{c}\text { AST } \\
\mathbf{x} T\end{array}$} & $r_{g}$ & $0.161^{\mathrm{NS}}$ & - & $-0.096^{\mathrm{NS}}$ & $0.095^{\mathrm{NS}}$ & $0.182^{\mathrm{N}}$ & 0.164 & - & 0.16 & $0.435^{* *}$ & $0.006^{\mathrm{N}}$ & - & \\
\hline & $r_{P}$ & $0.202^{\mathrm{NS}}$ & - & $-0.108^{\mathrm{NS}}$ & $0.090^{\mathrm{NS}}$ & $0.220^{*}$ & 0.192 & 0.037 & 0.31 & $0.538^{* *}$ & - & $-0.225^{*}$ & \\
\hline \multirow[t]{2}{*}{ TYP } & $r_{g}$ & $0.205^{\mathrm{NS}}$ & $0.091^{\mathrm{NS}}$ & $0.039^{\mathrm{NS}}$ & $0.273^{*}$ & $0.311^{\text {*** }}$ & $0.265^{*}$ & 0.122 & 0.34 & $0.373^{* *}$ & $0.362^{* *}$ & $0.310^{* *}$ & $0.735^{* * *}$ \\
\hline & $r_{P}$ & $0.240^{*}$ & $0.091^{\mathrm{NS}}$ & $0.054^{\mathrm{NS}}$ & $0.317^{* *}$ & $0.373^{* *}$ & $0.325^{*}$ & 0.211 & 0.50 & $0.431^{* *}$ & $0.440^{* *}$ & $0.470^{* *}$ & $0.751^{* *}$ \\
\hline
\end{tabular}

$\mathrm{r}_{\mathrm{g}}=$ genotypic correlation coefficient; $\mathrm{rP}=$ phenotypic correlation coefficient;

* Significant at $5 \%$ level; ** Significant at $1 \%$ level

NB: PH-Plant height $(\mathrm{cm})$, SP-Shoots per plant, CLL-Compound leaf length $(\mathrm{cm})$,

CLB-Compound leaf breadth (cm), CLA-Leaf area $\left(\mathrm{m}^{2}\right)$, NCL-No. of compound leaves plant ${ }^{-1}$,

TPP- Tubers per plant, TYPP -Tuber yield per plant (g), ASTW-Average single tuber weight (g) 
Table.2 Path matrix using genotypic correlation coefficient values

\begin{tabular}{|c|c|c|c|c|c|c|c|c|c|c|c|c|}
\hline & PH 30d & PH 45d & PH 60d & SP 30d & SP 45d & SP 60d & CLL & CLB & CLA & NCL & TPP & ASTW \\
\hline PH 45d & -0.424 & -0.257 & -0.220 & -0.157 & -0.193 & -0.205 & -0.130 & -0.080 & -0.089 & -0.070 & -0.075 & -0.031 \\
\hline PH 60d & -0.122 & -0.202 & -0.182 & -0.008 & -0.007 & -0.016 & -0.038 & -0.031 & -0.003 & -0.056 & -0.081 & 0.026 \\
\hline SP 30d & 0.466 & 0.813 & 0.899 & -0.082 & -0.070 & -0.032 & 0.179 & -0.032 & 0.272 & 0.196 & 0.226 & -0.045 \\
\hline SP 45d & -1.089 & -0.114 & 0.268 & -2.939 & -2.846 & -2.785 & -1.175 & -0.788 & 0.372 & -1.385 & -1.187 & -0.810 \\
\hline SP 60d & 2.081 & 0.166 & -0.354 & 4.422 & 4.566 & 4.481 & 2.050 & 1.119 & -0.030 & 2.068 & 1.479 & 1.190 \\
\hline CLL & -0.631 & -0.102 & 0.046 & -1.238 & -1.282 & -1.307 & -0.544 & -0.309 & 0.097 & -0.644 & -0.375 & -0.306 \\
\hline CLB & -0.001 & -0.001 & -0.001 & -0.001 & -0.002 & -0.002 & -0.004 & 0.000 & -0.001 & -0.001 & -0.001 & -0.001 \\
\hline CLA & 0.102 & 0.082 & -0.019 & 0.145 & 0.132 & 0.127 & -0.054 & 0.539 & -0.088 & 0.232 & 0.207 & 0.089 \\
\hline NCL & -0.147 & -0.011 & -0.213 & 0.089 & 0.005 & 0.052 & -0.122 & 0.115 & -0.706 & 0.162 & 0.076 & -0.274 \\
\hline TPP & -0.103 & -0.173 & -0.136 & -0.294 & -0.283 & -0.308 & -0.241 & -0.269 & 0.143 & -0.624 & -0.395 & -0.252 \\
\hline ASTW & 0.019 & 0.044 & 0.027 & 0.044 & 0.035 & 0.031 & 0.025 & 0.042 & -0.012 & 0.069 & 0.108 & 0.043 \\
\hline $\begin{array}{c}\text { TYPP } \\
\text { 75d }\end{array}$ & 0.089 & -0.154 & -0.061 & 0.336 & 0.318 & 0.286 & 0.265 & 0.202 & 0.474 & 0.493 & 0.490 & 1.220 \\
\hline
\end{tabular}

Residual effect $=0.05826$

NB: PH-Plant height $(\mathrm{cm})$, SP- Shoots per plant, CLL-Compound leaf length $(\mathrm{cm})$,

CLB-Compound leaf breadth (cm), CLA-Leaf area $\left(\mathrm{m}^{2}\right)$, NCL-No. of compound leaves plant ${ }^{-1}$,

TPP- Tubers per plant, TYPP - Tuber yield per plant (g), ASTW-Average single tuber weight (g) 
Maximum direct positive effect was exhibited by the shoots per plant at 45 days (4.566) followed by average single tuber weight (1.220), plant height at 60 days (0.899) and compound leaf breadth (0.539). This indicates that these traits contribute directly towards tuber yield much more than other characters and selection for these traits will be rewarding. The traits like compound leaf length, number of compound leaves, plant height at 30 and 60 days and shoots per plant at 30 and 45 days exhibited negative direct effect on yield.

\section{References}

Brown CR, Durst RW, Wrolstad R and Jong WD. 2008. Variability of phytonutrient content of potato in relation to growing location and cooking method. Potato Res. 51:259-270.

Brown CR, Culley D, Bonierbale $\mathrm{M}$ and Amoros W. 2007. Anthocyanin, carotenoid content, and antioxidant values in native South American potato cultivars. Hort Science. 42(7): 17331736.

Brown CR, Kim TS, Ganga Z, Haynes K, De Jong D, Jahn M, Paran I and Jong DW .2006. Segregation of total carotenoid in high level potato germplasm and its relationship to beta-carotene hydroxylase polymorphism. Am $J$ Potato Res. 83:365-372.

Brown CR .2005. Antioxidants in potato. Am J Potato Res .82:163-172.

Brown CR, Wrolstad R, Durst R, Yang CP and Clevidence B .2003. Breeding studies in potatoes containing high concentrations of anthocyanins. Am J Potato Res. 80:241-250.

Burton GW. 1952. Quantitative interaction in grasses. In: Proc. 6th Inter Grassland Congr. 1: 277-283.

Crisosto CH., Crisosto GM and Metheney P. 2003. Consumer acceptance of 'Brooks' and 'Bing' cherries are mainly dependent on fruit SSC and visual skin color. Postharvest Biology and Technology. 28. p. 159-167.

Desai NC and Jaimini SN. 1998. Correlation and path analysis of some economic characters in potato. J. Indian Potato Assoc. 25 (1\&2): 25-29.

FAO (Food and Agricultural Organization). 2017. FAOSTAT. Food and Agriculture Organization, Rome, Italy.

Jansen G and Flamme W. 2006. Coloured potatoes (Solanum tuberosum L.) anthocyanin content and tuber quality. Genetic Resources and Crop Evolution. 53: 1321-1331.

Khayatnezhad M, Shahriari R, Gholamin R, Jamaati-e-Somarin $\mathrm{S}$ and Zabihi-eMahmoodabad R. 2011. Correlation and path analysis between yield and yield components in Potato (Solanum tubersum L.). Middle-East Journal of Scientific Research 7(1): 17-21.

Luthra SK, Gupta VK, Kaundal B and Tiwari JK .2018(b). Genetic analysis of tuber yield, processing and nutritional traits in potato (Solanum tuberosum). Indian Journal of Agricultural Sciences 88 (8): 1214-1221.

Panigrahi KK, Pradhan J, Panigrahi P and Sarkar KK.2017.Genetic variability, character association, and path co efficient analysis of yield attributes for medium and late maturing potato cultivars. International Journal of Current Microbiology and Applied Sciences. 6(7): 2558-2566.

Sattar MA, Sultana N, Hossain MM, Rashid MH and Islam AKMA.2007. Genetic Variability, Correlation And Path Analysis In Potato (Solanum tuberosum L.) Bangladesh J. Pl. Breed. Genet., 20 (1) : 33-38.

Singh RK and Chaudhary BD. 1979. Biometrical methods in quantitative genetic analysis. Kalyani Publishers. Ludhiana. 


\section{How to cite this article:}

Nayak, S., A. Mishra, D. Ghosal and Sahu, G. S. 2020. Character Association and Path Analysis in Coloured Potato (Solanum tuberosum L.). Int.J.Curr.Microbiol.App.Sci. 9(04): 2889-2895. doi: https://doi.org/10.20546/ijcmas.2020.904.338 